Nordisk Tidsskrift for Kriminalvidenskab 2005

\title{
POLITIETS KONFLIKTHÅNDTERING I NORDEN
}

Av leder i Nordisk Forum for Megling og Konflikthåndtering, Dag Hareide

The author divides the role of the police into three ideal types: Warrior; Long Arm of the Law; and Conciliator. While the first role is marginal and the second is politically correct, it is the third role that comprises the everyday reality for Nordic police. Contrary to popular conceptions derived from the media, both empirical studies and police law indicate that crime fighting is only a minor part of police work. Conflict management is an art, but also a science. The article pinpoints two factors that make some officers better than others at handling conflicts: the first is an absence of pre-judgments, while the second is the possession of skills in interactions that de-escalate conflicts. "Skills in practice" is launched as an educational approach that optimises attitudes, knowledge, and skills training. It combines the interest of self protection with the de-escalation of conflicts. Four opportunities/ threats are discussed: internationalization; the never-ending growth of a need for protection in the welfare society; conflict as a welfare good that the police should not steal from the public unnecessarily; and ways by which a high level of trust in the police can be maintained in the Nordic countries. Two internal challenges are discussed: when measurable outcomes become the goal; and the reaction of the police to public complaints.

Er det noe spesielt som karakteriserer politiet som yrkesgruppe i forhold til konflikthåndtering? Jeg kan nevne to ting: For det første driver politiet den eneste landsomfattende døgnåpne utrykningstjenesten 365 dager i året. Den som har vært med på politipatruljer vet at det nesten er ingen grenser for hvilke konflikter folk forventer at politiet skal ordne opp i! For det andre er det politiet som ved lov har myndighet til å bruke makt i konflikter. Politiet tar over når andre ikke lenger kan takle en konflikt som eskalerer mot vold. Dette gir politiet en dobbelt rolle; generalisten som må forholde seg til folks vanlige konflikter i all sin alminnelighet, og spesialisten som bruker makt på vegne av samfunnet i eskalerte konflikter eller overgrep.

Men driver politiet først og fremst med konflikthåndtering? Politiet skal jo "fakke tyver og mordere"? Det er vel svaret du får dersom du spør en elev i barneskolen. Dersom du bygger din kunnskap om politiet på nyhetssendinger og kriminalserier på TV tenker du at politiet først og fremst er kriminalitetsbekjempere.

\footnotetext{
- Title in English: The Police as Conflict Managers. Original in Norwegian.
} 
Det finnes et medieskapt bilde av politiet som stadig jakter etter farlige forbrytere. ${ }^{1}$ Og hva tenker politiet selv? Kanskje tenker mange: "vel må vi ta oss av mange konflikter, men egentlig er vi jo her for å bekjempe kriminalitet"?

Derfor er det overraskende for de fleste at politiet driver svært lite med kriminalitetsbekjempelse. Da den moderne politisosiologien etablerte seg på 1960-tallet, var det ett av dens funn. Beregningene fra andre vestlige land angir en andel på 10 $-30 \% .{ }^{2}$ En norsk undersøkelse viser at under $10 \%$ av hendelsene i vanlig ordenstjeneste i Oslo førte til forelegg, innbringing eller pågripelse. ${ }^{3} \mathrm{Og}$ dersom vi går til det normative; politiloven, så sier f.eks. den norske at politiets oppgaver bl.a. er å "beskytte og verne person, eiendom og fellesgoder", "yte borgere hjelp og tjenester i faresituasjoner", "samarbeide med andre myndigheter og organisasjoner". Disse oppgavene får en plass sideordnet det "å avdekke og stanse kriminell virksomhet". ${ }^{4}$

"Å håndtere konflikter" kan dermed være en mer passende definisjon på politiets jobb enn "å bekjempe kriminalitet". Nå kan dette lett bli en forvirrende bruk av ord. Når politiet fremmer en påtale i en kriminell sak så kan det oppfattes som en konflikt i følge vanlig definisjon av det begrepet. Konflikter er slik sett et overordnet begrep som kan bli til rettssaker, til kriger, til hverdagslig megling m.m. For å sortere litt i dette mangfoldet vil jeg presentere tre idealtypiske konflikthåndteringsmodeller for politiet:

\begin{tabular}{|l|l|l|l|}
\hline Metaforen om politiet & KRIGEREN & $\begin{array}{l}\text { LOVENS } \\
\text { LANGE ARM }\end{array}$ & FORLIKSPERSON \\
\hline Styring & Kommando & Regelstyring & Mål og verdistyring \\
\hline Problemfokus & Fienden & Kriminaliteten & Skadelige konflikter \\
\hline Metode & Nedkjempe & Veilede, påtale & $\begin{array}{l}\text { Samtale, veilede, meg- } \\
\text { le. Ordne på stedet. }\end{array}$ \\
\hline Grunnvitenskap & Militær vitenskap & Jus & $\begin{array}{l}\text { Psykologi og } \\
\text { samfunnsvitenskap }\end{array}$ \\
\hline Verdier & $\begin{array}{l}\text { Det gode mot } \\
\text { det onde }\end{array}$ & $\begin{array}{l}\text { Dømmende } \\
\text { rettferdighet }\end{array}$ & $\begin{array}{l}\text { Gjenopprettende } \\
\text { rettferdighet }\end{array}$ \\
\hline Folkerett & Humanitær lov & Menneskerettigheter & Menneskerettigheter \\
\hline
\end{tabular}

I Norden har den første modellen vært perifer, den andre har vært politisk korrekt, mens det tredje har fylt politiets hverdag.

Den første modellen kan skimtes i mellomkrigstiden, hvor enkelte nordiske land nærmet seg en organisering av politiet som "gendarmeri", en mer militær organisering av politiet lik land som Tyskland og Frankrike. ${ }^{5}$ I dag kan metaforen dukke opp som i "krig mot organisert kriminalitet" og "krig mot terrorisme". Noen vil spørre om dette preger visse av politiets spesialorganer som beredskapstropper og politiets sikkerhetstjeneste. ${ }^{6}$ Militarisering har imidlertid vært og er mer perifer 
i Norden enn i flere av de vestlige demokratier. ${ }^{7}$ Det norske politirolleutvalget fra 1981 oppsummerer ti prinsipper for politirollen.

Politiet skal:

1) forankres i samfunnets demokratiske og humanistiske verdier

2) ha et sivilt preg

3) være enhetspoliti

4) være desentralisert

5) være generalister

6) virke i samspil med publikum

7) være integrert i lokalsamfunnet

8) ha bred rekruttering

9) legge hovedvekt på forebyggende arbeid

10) være underlagt effektiv kontroll fra samfunnets side.

Disse ti valg for politiets organisering er samtidig ti prinsipper for konflikthåndtering som hindrer militarisering av politiet. ${ }^{8}$

Den dominerende metaforen i dag er forestillingen om politiet som "Lovens lange arm". I et rettssamfunn må det fortsette å stå sterkt. Men den kan inngå i et jevnbyrdig samspill med den tredje modellen med politiet som "forliksmann/ forlikskvinne". I denne tredje modellen vil politiet ofte "ordne saken på stedet"; utenfor rettsapparatet og ofte mer basert på skjønn enn lov. I politiforskningen har forholdet mellom disse modellene blitt formulert som en spenning mellom "legitimitet og effektivitet". ${ }^{9} \mathrm{Og}$ den spenningen og balansen er det viktig å holde på.

Med den nye interesse for "Restorative Justice" blir det stilt nye spørsmål om hva som er å oppfatte som det legitime. ${ }^{10}$ Restorative Justice er vanskelig å oversette til skandinavisk. Noen oversetter det som "deltagende rettspleie" som gjengir begrepets vekt på prosess eller "gjenopprettende rettferdighet" og "forsoningsjustis" som reflekterer begrepets vekt på resultatet og etikk. Det er partene (offer og gjerningsmann og evt. deres nettverk), evt. ledet av en tredjepart som megler/veileder, som blir enige om en avtale hvor gjerningsmannen kan rette opp i skaden som er gjort. Rettferdigheten ligger i at partene godtar og opplever en gjenoppretting av skaden. Den straffende rettferdighet forholder i stedet rettferdigheten til lovparagrafer. Den straffende rettferdighet sier seg å gi likhet for loven. Men det skjer ikke ved at man ser langt og meget, men ved at man ser bort fra så meget. Den gjenopprettende rettferdighet ligger ikke i en straff, men i en konfrontasjon/samtale med en gjenopprettende handling. Den er mer fleksibel fordi den kan ta hensyn til bredden i situasjonen og lengden $i$ et forhold som skal gjenopprettes. 
Politiets kan bidra til gjenopprettende rettferdighet ved å overføre saker til konfliktråd og andre former for megling. Men kan dette også prege politiets egen praksis? Gjenopprettende rettferdighet har blitt et begrep i politiarbeidet i Australia, Canada og USA. I Europa er forsøket med "restorative policing" hos Thames Valley Police i England best kjent. De kan vise til gode resultater blant annet i forhold til ofrenes tilfredshet og nedgang i gjentagelseskriminalitet. ${ }^{11}$ Et mer begrenset fors $ø \mathrm{k}$ med politiet som meglere foregår nå i Nord-Trøndelag i Norge. ${ }^{12}$ Det er viktige kritiske spørsmål som stilles til slike forsøk, men tenkningen bak "gjenopprettende rettferdighet" vil skape endringer både i vårt straffesystem og politiets "Ordne på stedet".

\section{Politiet som politikernes drapsmenn}

Politiet er en yrkesgruppe som er svært sårbar og volatil under skifter i statenes politikk. Dette er spesielt farlig for idealmodellen: "krigeren". I forrige århundre vet vi at politi i diktaturstater sto for de verste myrderiene i det blodigste av alle århundrer - og langt flere ble drept av politi enn av forbrytere. Beregninger kan tyde på at maksimum 20 millioner ble drept av "forbrytere", mens ca. 200 millioner ble drept av militæret og politiet. ${ }^{13}$ De fleste ble altså drept av folk som ble drevet fram av ideologier som kommunisme, nazisme, diverse religioner, nasjonalisme og til og med demokrati. Vold er slik sett langt farligere fra dem som tror de gjør noe riktig, enn de som vet de gjør noe galt. Og politiet har ikke stått mye tilbake fra de militære i disse myrderiene. Politi i diktaturstater, som KGB, SS m.fl. som ble organisert ut fra idealmodellen: "krigeren", har drept mange titalls millioner. Stalin brukte KGB når han rensket den militære ledelsen. I Norge er den tyske okkupasjonen et traume i historien. Store deler av det norske politiets spilte en tvilsom rolle (for å si det mildt), noe stadig nye generasjoner politifolk bør lære om. ${ }^{14}$ Det gjelder ikke minst når man skal sendes verden rundt i tjeneste for alle slags regimer. Politiske endringer i demokratier berører politiet ovenfra gjennom politiske endringer så vel som nedenfra gjennom sosiale opprørsbevegelser. ${ }^{15}$

Vi kan ikke forvente at politiet skal ha sin hovedfokus i konflikthåndteringskunnskap på makronivå om overordnede samfunnsspørsmål, slik de fleste mastergrader i temaet har i de nordiske land. Hovedfokus vil for politiet være på et mikronivå i mellommenneskelige møter. Konflikthåndtering har utviklet seg til en vitenskap med sin egen forskningstradisjon. Men det er også en kunst og et håndverk. Noen har det i seg. Det gjelder ikke minst eldre politifolk, som gjennom et helt yrkesliv har taklet et sant mangfold av konflikter. Det ligger store muligheter og utfordringer i møtet mellom den "tause" erfaringsbaserte kunnskap som finnes i nordiske politifolks praksis - og en forskningsbasert teori med internasjonalt tilfang. 


\section{Når en feilparkering blir til et gateslagsmål}

Internasjonal forskning har vist at det er sterke individuelle forskjeller mellom hvor godt politifolk takler konflikter. ${ }^{16}$ I politikorpsene kjenner man til både han som unnviker konflikter, og "kranglefanten" som eskalerer en feilparkering til et gateslagsmål. Går det an å forutsi hvem eller hva som skaper problemer? Den internasjonale forskningen har gjort mange forsøk på å analysere hva som styrer politiets skjønnsmessige beslutninger. Oftest dreier slik forskning seg om enkle effektvariabler som innbringelse eller registrert maktbruk. Generelt viser de at bakgrunnsvariabler hos politifolkene forklarer lite av forskjellene i disse effektvariablene. Faktorene som alder, holdninger, organisasjonsforhold, kjønn ${ }^{17}$ og legale omstendigheter har generelt liten forklaringskraft.

Men to andre forhold synes å gi vesentlige utslag: For det første at personen som politiet møter anses som "en slask", for å bruke en upassende norsk politisjargong $^{18}$, og for det andre at personen provoserer og ikke er høflig og føyelig. ${ }^{19}$ "En slask" er en person som gjennom sin framtoning framstår mistenkelig, som regel med lav status. Det at politiet diskriminerer mellom borgere bør vel ikke forbause noen. Diskriminering betyr "å skjelne". Politijobben består nettopp i å skjelne ut de mistenkelige. Problemet er naturligvis at dette kan feste seg i et mønster av for-dommer og utvikle seg til stereotypifisering, klassehovmod, etnosentrisme og rasisme. Å skille mellom snørr og barter er avgjørende i politiets kompetanse. Dette er et viktig fokus for politiopplæringen.

Kanskje enda viktigere er det å fokusere på det andre punktet: motstanden fra den politiet henvender seg til. Det fører oss over i selve interaksjonen. Her kan kunnskapen om konflikthåndtering gi oss mer forståelse. Er det ofte slik at politiet ubevisst framprovoserer en konflikt? Et forskningsprosjekt fra Australia har gjennom mer avanserte metoder forsket på utfall av forskjellige taktikker som politiet bruker. ${ }^{20}$ De tok utgangspunkt i den språklige kommunikasjonen i konfliktsituasjonen som: å forklare årsaken til politiets inngripen, å bruke spørsmål for å kontrollere en situasjon, å bruke støttende utsagn til anklagede i første fasen og å holde tilbake trusler eller reformulere trusler. Kortfattet dreier det seg om teknikker for å berolige og de-eskalere en konflikt som er ABC i konfliktfaget. De som behersket disse teknikkene løste konfliktene klart bedre. Dette flytter fokus fra personenes bakgrunn til politifolks faktiske ferdighet. Politifolk etablerer som andre yrkesutøvere "en måte å være på" i yrket. Kanskje fester det seg allerede første året når man tar på seg uniform. "For mange forstår ikke at de kan smile, når de får uniformen på" for å sitere en eldre politimann. Det motsatte av humor er som kjent ikke alvor, men selvhøytidelighet. Ofte går dette seg fast $\mathrm{i}$ et spor tidlig og forblir der. 


\section{Ferdigheter og følelser}

Derfor bør man fokusere på "ferdigheter i praksis" i politiets kompetanse i konflikthåndtering. Det er et sluttprodukt overordnet kunnskap og holdninger. Et evalueringsutvalg oppsummerte 25 programmer i norsk skole som skulle føre til sosial kompetanse hos elever. De konkluderte med to råd: 1) å vektlegge ferdighetstrening framfor generelle holdningskampanjer, 2) å ikke lage kunstig instrumentalistisk trening, men å trene i en naturlig sammenheng. ${ }^{21}$ "Ferdighet i praksis" bygger på holdninger og kunnskap, og de må også festes i følelser og kropp.

Vi vet jo at det er lett å løse konflikter så lenge man ikke er redd, sint eller såret. Derfor avsløres "konflikteksperten" som krangler med ektefelle og barn - på hjemmeplan. Politiet avsløres også på gateplan. Knapt noen annen yrkesgruppe - selv ikke fotballdommere - vil måtte regne med å bli så åpenbart provosert fysisk og psykisk i jobben. Av politiutdannede i tjeneste i Norge har $61 \%$ blitt utsatt for vold og trusler siste år, mot $6 \%$ hos folket som helhet. ${ }^{22}$ Godt innlærte ferdigheter hjelper ikke bare for å løse en konflikt, men også for egen sikkerhet. Det kan sees på som to sider av samme trening. En FBI-studie over politifolk som ble skutt i tjenesten viser at disse skilte seg ut holdningsmessig med å være godtroende, og ferdighetsmessig ved lett å se bort fra innlærte rutiner. ${ }^{23}$ I Sverige driver Polishögskolan nå et etterutdanningsprosjekt av halvparten av politistyrken hvor kombinasjonen av disse to hensyn: selvforsvar og konflikthåndtering holdes sammen. ${ }^{24}$ Dette kan sees på som en reaksjon på så vel politimordene i Malexander 1999 og demonstrasjonene i Göteborg 2001.

\section{Må sitte i kroppen}

Ferdighetstrening må gjentas til man kan den automatisk og intuitivt. Kunnskapen om konflikthåndtering må sitte i kroppen - også en redd eller en sint kropp. Og når man har det automatisk i kroppen, må man enda et nivå opp; hvor man kan variere.

Kommunikasjonsteoretikere sier at ordene du sier, betyr mindre enn måten du sier det på. Det meste av inntrykket kommer fra tonefall og kroppsspråket. ${ }^{25} \mathrm{Er}$ dette reflektert i Politihøgskolenes læreplaner eller i politidistriktenes veiledninger? Skolene legger vekt på arrestasjonsteknikk naturlig nok. Men hva med den kroppslige teknikk i det store flertall av møter som ikke fører til arrestasjon? Hva med kroppsspråket de 10 sekundene du har fra døra i bilen fram til gjengen som står foran kjøpesenteret? Det er avgjørende. Kroppsspråket inkluderer en rekke ferdigheter som bruk av rom og avstand, påkledning, stemmeføring, stemmeleie, hodebevegelser, berøring, ansiktsuttrykk, øyekontakt, håndsignaler, latter, gjentagelse av bevegelser, symbolbruk, seksuelle signaler, pusteøvelser, kroppspositur m.m. ${ }^{26}$ Ikke minst i forhold til grupper hvor det språklige er vanskelig - som folk med andre morsmål og psykiatriske pasienter - vil kroppsspråket være enda viktigere. Kroppsspråket har visse universelle trekk som smilet, men har mange kulturelle og individuelle 
forskjeller, mange "språk og dialekter". ${ }^{27}$ Her er mye å lære. I Norden er idrett blitt selve kroppsøvingsfaget - også for politiet. Det dreier seg om slike ting som å løpe fort og lenge og løfte mye. Det evalueres i rent fysiske tester. Kropp og sjel/ånd er noe atskilt $\mathrm{i}$ vår tradisjon. Den lutherske religion er kanskje en av de minst kroppslige religiøse tradisjonene i verden. Vi kan ha godt av noe tilførsel fra andre tradisjoner. Politiet trenger en annen form for kroppsøving som smelter sammen det mentale og fysiske; gjerne med inspirasjon fra japanske mentale kampsporter, indiske meditative kroppsbeherskelser og moderne vestlige dramafag. Den mest omfattende evaluering som politiet daglig utsettes for av tusenvis av folk i Norden dreier seg om kroppsspråk. Foregår det en tilsvarende evaluering i politiskolene?

\section{Fire ytre muligheter/trusler}

Hvilke utfordringer står nordisk politi overfor i sin konflikthåndtering tida framover? Kanskje burde jeg heller snakke om problemer eller trusler? Det minner om en politimester i Nord-Norge som hadde lært dette at problemer egentlig var utfordringer, og etter hvert at utfordringer egentlig var muligheter. Inntil han en dag satte seg ned med hodet i hendene og sukket: "Får vi flere muligheter nå, så går vi konkurs!".

Jeg vil velge ut fire hovedtendenser i samfunnsbildet som påvirker politiets rolle som konflikthåndterere, så kan leserne avgjøre om de mest er trusler eller muligheter.

\section{1) Internasjonalisering}

Internasjonaliseringen har flere konsekvenser for politiet; blant annet:

- $\quad$ Økende kriminalitet organisert over landegrensene med narkotika, trafficking, økonomisk kriminalitet m.m.

- Økende samarbeid med politi i andre land, blant annet ved nordiske politifolks tjeneste i utlandet.

- $\quad$ Økende innvandring

Dette krever økt kompetanse bl.a. i etterforskning, og ikke minst i konflikthåndtering. Særlig vil det dreie seg om flerkulturell konflikthåndtering. Måten man forholder seg til konflikter er noe av margen i en kultur. England, som historisk har vært en varsellampe for hva som kan komme til nordisk politi, har opplevd kriser og sviktende tillit til politiet på grunn av deres behandling av innvandrere. ${ }^{28} \AA$ skrive om dette ville krevd en egen artikkel. Jeg kan bare gi en kort kommentar. Etnosentrisme består i at enkelthandlinger som blant egen gruppe vil bli sett på som handlinger fra individer, vil når det gjøres f.eks. av en somalier bli sett på som typisk for somaliere som gruppe. Denne etnosentrismen er vanlig hos folk flest, og sikkert også i politiet. 
Hvordan kan man møte det? Problemet er ikke at politiet diskriminerer = "skjelner", men at de ikke diskriminerer/skjelner nok. Man skal ikke bare diskriminere/skjelne mellom nordmenn og nordmenn, men også mellom somaliere og somaliere.

Holdningskampanjer er bra. Men man trenger ikke elske innvandrere. Det er nok å behandle dem høflig og fair. Mitt nøkkelord vil være: respekt (som etymologisk betyr "å se om igjen, en gang til"). Kunnskap om andre kulturer er nødvendig. Men litt kunnskap om somaliere eller afrikanere kan føre til at det som er fordommer blir framstilt som vitenskap. Noe mer kunnskap derimot fører ofte til fruktbar forvirring. Etter fem år i Etiopia antar denne forfatteren at de kulturelle forskjellene blant de over 70 språkgruppene i Etiopia, antagelig er større enn forskjellene innen hele Europa. Hadde jeg vært i Etiopia en måned ville jeg kanskje sagt noe om "hvordan etiopiere er", etter 5 år ble det svært komplisert. Andre er i stand til å si noe om "hvordan afrikanere er". Hobbyantropologi for politifolk vil som regel bety at man bare stokker om på fordommene sine.

Kunnskap om andre kulturer skal ikke gi konklusjoner om hvordan de er, men heller nysgjerrighet og åpenhet for det som er annerledes. Nordiske land scorer høyest i Europa på å godta forskjellige grupper av "annerledes mennesker" som naboer. Svenskene vil helst ikke ha naboer som er høyreradikale, danskene vil ikke ha muslimer og finnene ikke romafolket; sigøynere. Men samlet er Norden mest tolerante - i teorien. Derimot scorer vi svært lavt på å godta at de skal fortsette å leve ut sin kultur. ${ }^{29}$ Det kan synes som det er en nordisk tendens som sier: "Jeg godtar deg som nabo, men du bør bli som oss".

Igjen synes det som "ferdigheter i praksis" er viktigst; i den forstand at hvert menneske skal møtes respektfullt og profesjonelt. Den multietniske profesjonalitet har en kjerne som består $i$ at enhver skal behandles som et individ med nysgjerrig åpenhet for å forstå denne personens livsverden. En antropologisk undersøkelse om dansk politis omgang med unge etterkommere av innvandrere, beskriver hårreisende feil i enkle konfliktsituasjoner. ${ }^{30}$ Undersøkelsen viser at mer kunnskap og andre holdninger trenges. Men beskrivelsen av konfliktene, viser at det som først og fremst mangler er alminnelige anstendige regler for hvordan man oppfører seg overfor et annet menneske. Det er mangel på generell profesjonalitet som er den viktigste holdningssvikten. Politiet undertrykker innlærte ferdigheter i møte med innvandrerungdom.

For nordisk politi som skal arbeide i andre land, vil både ferdigheter og kunnskaper i flerkulturell konflikthåndtering være enda viktigere. I løpet av forrige århundre endret krigene karakter på mange måter. Særlig er to endringer tydelig: Fra $\mathrm{i}$ hovedsak å være kriger mellom land, er nå ni av ti kriger borgerkriger. Fra i hovedsak å ramme militære styrker, er det nå åtte av ti døde som er sivile. En borgerkrig får ofte en glidende overgang til organisert kriminalitet, forskjellene synes for tiden å bli mindre. Alt dette har gjort at politikompetanse har blitt mer relevant i kriger. 
Enda mer relevant er politikompetansen i overgangsperioden når et land etter borgerkrigen skal utvikle seg mot et demokrati. ${ }^{31}$ Sergio Vieira de Mello som ledet FNs observatørkorps i Irak, sa rett før han ble drept av en bilbombe at om det var en ting han hadde lært fra flere slike overgangsperioder så var det at politiet og ikke militæret innehadde den kompetansen som trengtes. Utfordringene blir kvalitativt annerledes når FNs politi går fra en veilederrolle til en operativ rolle som i Kosovo og Øst-Timor.

\section{2) Velferdssamfunnets umettelighet}

De skandinaviske velferdssamfunnene la det moralske ansvaret for folks velferd på staten. Staten skulle sikre mot sykdom, alderdom, ulykker osv. Velferdsøkningen synes å også innebære at folks krav om trygghet og bistand til konfliktløsning øker. ${ }^{32}$ Når naboen bråker så ordner man ikke opp sammen med andre naboer, men ringer politiet. Dette ligner på helsesektorens som opplever stadig økende behov for flere helsetjenester, til tross for at folk antagelig er friskere enn noensinne. Folks økende behov for trygghet og for å løse sine konflikter synes umettelig. Dette kan imøtekommes ved:

1. At politiet og andre offentlige konflikthåndterere får mer ressurser og/eller blir mer effektive.

2. At det overføres til nye sikkerhets-aktører på et privat marked som skrur prisene opp.

3. Ved en motbevegelse som gir konfliktene tilbake til folk.

"Et demokratisk samfunn kan ikke tåle et politi som er i stand til å løse alle oppgaver." skriver det norske Politirolleutvalget. ${ }^{33}$ Samtidig som politiet er den institusjonen som har størst tillit i Norden, så tenker vi at begrepet "Politistat" er noe negativt.

Jeg har sammenstilt to statistikker over land i Europa ut fra hvor mange personer som har stor/ganske stor tillit til politiet og hvor mange politi som finnes i forhold til befolkningstallet. Statistikken er metodisk tvilsom, men viser en tendens til at jo færre politi det er i forhold til folketallet, jo mer tillit har folk til politiet. ${ }^{34}$

\begin{tabular}{|l|c|c|}
\hline LAND & Folkpr.politiansatt & $\%$ tillit til politiet \\
\hline Norge & 597 & $88 \%$ \\
\hline Finland & 594 & $90 \%$ \\
\hline Sverige & 520 & $76 \%$ \\
\hline Danmark & 505 & $91 \%$ \\
\hline Luxembourg & 375 & $72 \%$ \\
\hline Storbritannia & 375 & $70 \%$ \\
\hline Irland & 339 & $84 \%$ \\
\hline
\end{tabular}




\begin{tabular}{|l|l|l|}
\hline Osterrike & 311 & $66 \%$ \\
\hline Nederland & 308 & $64 \%$ \\
\hline Belgia & 299 & $56 \%$ \\
\hline Tyskland & 284 & $74 \%$ \\
\hline Hellas & 260 & $28 \%$ \\
\hline Frankrike & 252 & $66 \%$ \\
\hline Italia & 237 & $67 \%$ \\
\hline Spania & 225 & $59 \%$ \\
\hline Portugal & 215 & $66 \%$ \\
\hline
\end{tabular}

Jeg har ikke sammenlignbare data for Island, men andre data tyder på at de antagelig ville toppet listen både for færrest politifolk og mest tillit. De nordiske land har altså høyest tillit til politiet (med Sverige noe bak de fire andre landene), og lavest antall politi i forhold til folketallet. Dette betyr naturligvis ikke at dersom vi reduserer antall politi, så øker tilliten til politiet. Begge tallrekkene viser hen til bakenforliggende årsaker som dreier seg om hva som skaper tillit til samfunnets institusjoner. En lærdom er at politiet ikke nødvendigvis skal være helten som alltid løser andres konflikter, men i stedet utvikle en egen evne til å plassere konflikten hos den som eier den. Politiet skal ikke stjele konflikten fra folk. Jeg spurte en lensmann fra Midt-Norge om hvordan han løste alle konfliktene som kom fra publikumshenvendelsene i hans store distrikt. "90 \% tar jeg på telefonen", sa han, "jeg bare ringer en av naboene og ber dem stikke innom."

\section{3) Konflikt som demokratisk velferdsgode}

Det er ikke nødvendigvis dårlig at et samfunn har et høyt konfliktnivå. En av de viktigste innsikter i konfliktforskningen er det noe selvfølgelige at konflikter kan være bra. Konflikter tydeliggjør skjult undertrykkelse. Vi oppdager nå vold mot barn og kvinner som vi har oversett før. Vi ser nå undertrykking av våre minoriteter; samer og de reisende, som vi har oversett før. Konflikter kan føre til personlig utvikling og samfunnets utvikling. De eneste mennesker som ikke lever med motsetninger, kalles lik. Derfor er det feil å stjele konflikter fra folk - slik advokater og sosionomer og politifolk lett kan komme til å gjøre. ${ }^{35} \mathrm{Og}$ dette er den andre noe selvfølgelige innsikten i den moderne meglerbevegelsen: at konflikter løses best ved at de som eier den selv får delta i løsningen.

Disse to enkle innsiktene er utgangspunkt for den moderne meglerbevegelsen. Politiet er hovedleverandør til konfliktrådene og "medling vid brott". Disse meglingsordningene burde utvikle seg til å være en like selvfølgelig følgesvenn for politiet som rettsapparatet. Politiet burde også være oppmerksom på de andre meglingsordningene som har vokst fram - som familiemegling, elevmegling, ad- 
vokatmegling, rettsmegling, nabomegling og en økende aktivitet med konflikthåndtering i "varme konflikter" $\mathrm{i}$ arbeidslivet. ${ }^{36} \mathrm{Vi}$ kan anta at et demokrati vil $ø$ ke antall konflikter fordi flere mennesker vil bli involvert $\mathrm{i}$ beslutningene. Vi kan videre anta at et demokrati som er i sterk endring, vil øke frekvensen av disse konfliktene. Politiet kan ikke møte denne endringen ved å være heltene som løser alt for folk. Det beste er at partene løser det selv ved samtale og forhandling. Det som ikke løses slik, bør som regel først gå til megling - frivillig og fredelig - før politi eller rettssak kobles inn. Eventuelt kan politi opptre som meglere. Det dreier seg om et verdivalg, men også om en nødvendig effektivisering av et konfliktløsningssystem som ellers ville ta for mye skattepenger og tid.

\section{4) Hvordan beholder politiet tillit?}

Den siste tendensen har vært der lenge. Og kanskje overrasker det at den varer ved. Det er tendensen til den høye tilliten til politiet som institusjon. Politiet scorer blant de høyeste i samtlige nordiske land på disse jevnlige undersøkelsene om tillit til institusjoner. Mens f.eks. rettsapparatet har gått ned i Norge over $10 \%$ de siste par tiår, har politiet holdt seg oppe. Det er noe uklart hva vi kan utlede av dette. For eksempel har publikum svært liten tillit til at politiet skal løse deres problemer med hverdagskriminalitet. Bare et mindretall har tillit til at politiet vil løse tyveri og voldssaker. ${ }^{37}$ Tilliten er altså ikke spesifikk til politiet som kriminalitetsbekjempere, men heller generell til politiet som institusjon. Det finnes lite forskning som viser hva som bygger opp tilliten til politiet hos publikum, og hva denne tilliten er rent fenomenologisk eller diskursteoretisk. Dette er et felt innen politiforskningen som roper på mer empiri og teori. Er det kanskje viktigere for politiet å øke folks tillit og trygghetsfølelsen enn å løse faktisk kriminalitet og konflikter? Jeg kan skimte noen strategier i det tillitskapende arbeidet.

A) Den første "populistiske" strategien er å forstørre problemene og å skape fiendebilder. Dersom befolkningen ser kriminalitet og uorden som samfunnets viktigste onde, vil man se politi som løsningen.

B) Den andre "markedsorienterte" strategien er å skape tillit gjennom en markedsorientert PR strategi. Det viktige er da "image" og "performance". ${ }^{38}$

C) En tredje "institusjonsbyggende" strategi vil forholde seg til etiske holdninger og prinsipper om hva som er tillitskapende og fredsbyggende i politirollen.

Men tillit kan ikke bare dreie seg om at folk skal ha tillit til politiet. Tillit er noe gjensidig. Hvordan får politiet tillit til folk; for eksempel grupper av innvandrere? Kan "tillitsbygging" og "konflikthåndtering" flettes sammen? Konflikthåndtering er en prosess fra det proaktive/forebyggende videre til det reaktive/ordenstjeneste og til det tredje som oftest er utelatt i politiets lærebøker: det transformative. Hva 
sier man dagen etter i glattcella? Er det plass til "Dagen-Derpå-Dialogen"? Har politiet evnen til å ta oppgjør og skape forsoning? Dette er en viktig bro over til tillitsspiralen. Dersom man satser på den tredje modellen for tillitsbygging vil det være viktig å utvikle et bevisst forhold mellom politiets ferdigheter og etiske nøkkelord som går igjen i ledende fredsbyggingsteori. ${ }^{39}$ Sannhet/Ærlighet, rettferdighet/rimelighet, sikkerhet/trygghet og forsoning/tilgivelse.

\section{To indre utfordringer/problemer}

Dette leder fra de ytre muligheter/trusler til de indre utfordringer/problemer innen politiet. Jeg vil begrense det til to utfordringer. Begge angår både strukturen/måten politiet ledes på og kulturene/arbeidspersonlighetene i politifellesskapet. ${ }^{40}$

\section{1) Når det målbare blir målet}

Politireformen 2000 i Norge og tilsvarende organisasjonsendringer i andre nordiske land fører til at politiet styres mindre etter regelstyring og mer etter mål og resultatstyring. ${ }^{41}$ Dette harmonerer med en ny vektlegging mellom modellene jeg presenterte i begynnelsen av dette kapittelet. Men målrasjonalitet er ikke eneste alternativet til regelstyring. Man kunne f.eks. ha fokusert mer på verdibasert ledelse. ${ }^{42}$ Stortingsmeldingen om Politireform 2000 i Norge reflekterer ikke dette valget, selv om midler som styringsdialog og inspeksjon kan invitere til det. ${ }^{43}$ Det avgjørende blir at sanksjoner og belønninger synes å skulle knyttes til tall for politiet prestasjoner. Når politimesteren får flere bevilgninger eventuelt høyere lønn ut fra noe målbart, så blir det lett målet. Der vil påtalemyndigheten ha et forsprang. ${ }^{44}$ De forholder seg naturlig nok til straffesaksbehandlingen og ber om tall på oppklaringsprosent og saksbehandlingstid. Men hva forteller prosent oppklarte forbrytelser om de mål politiet har? ${ }^{45}$ En slik fiksering på enkelttall, kan føre til "tunnellsyn". Et annet problem er at en slik statistikk er lett manipulerbar. En politisjef kan sette styrkene inn på å kontrollere biler og å taue inn og ut gatenarkomane i arresten og slik øke oppklaringsprosenten raskt uten at det forbedrer vilkårene for folk flest.

Antall forbrytelser i kriminalstatistikken kan antas å si noe mer. Men for det første sier den ikke noe om kriminalitet som ikke anmeldes ${ }^{46}$, for det andre så har endringer i kriminalstatistikken antagelig mindre med politiets arbeid å gjøre enn mange tror ${ }^{47}$, for det tredje forholder den ikke seg til hva som skjer i de største delene av politiets arbeid som ikke fører til påtale, og for det fjerde forholder den seg heller ikke til spørsmål om trygghet og tillit. Disse statistikkene blir som en bikini, de avslører noe, men skjuler det viktigste. Det arbeides nå med å få fram andre tall for politiets innsats og folks forventninger, men det er ennå ikke prøvd ut. ${ }^{48} \mathrm{I}$ år er det 30 år siden dette ble etterspurt i Norges første politisosiologiske bok. ${ }^{49}$ 
Og hvorfor ikke få fram folks prioriteringer for politiet. Rogaland Politidistrikt i Norge lagde i 2002 en publikumsundersøkelse hvor man spurte publikum om deres holdninger til politiets arbeid, og samtidig spurte politiet om hva de trodde publikums holdninger var. Det kom fram interessante sprik som 1) politiet trodde publikum hadde mindre tillit til dem enn de hadde, 2) politiet trodde publikum fryktet kriminalitet og uorden mer enn det de gjorde, 3) mens publikum var mest redd for trafikken, trodde politiet de var redde for vold og tyveri, 4) politiet trodde at politiets synlighet var viktigere enn det publikum faktisk syntes. 5) for publikum var politiets høflighet viktigere for tillit mens politifolk la mer vekt på at de tok saken alvorlig. ${ }^{50}$

Det er makt i de tellende hender. Så lenge størstedelen av politiets daglige arbeid ikke måles, risikerer vi at det ikke verdsettes, og det blir lavstatus innen politietaten. Dermed er vi over på spørsmål om kulturene blant politifolk. Er det slik at jobben har høyere status i politiet jo mer konflikten har eskalert? Er det forebyggende nederst, deretter ordenstjeneste, så beredskapstropp og etterforskning? Dette står i tilfelle i motsetning til instruksen som sier at man skal prioritere forebyggende og løse konflikten med så lite makt som mulig. Skrytes det av de tøffe og skarpe konfrontasjonene eller skrytes det av hvordan man greidde å forebygge eller løse konflikter på den mjuke måten?

\section{2) Hvordan takler man egne feil og konflikter?}

Den andre utfordringen gjelder evnen til å si unnskyld, den transformative fasen i politiets konflikthåndteringssirkel: Evnen til oppgjør og forsoning. Politiet i Norden gjør daglig ting som krenker medmennesker dypt. Dette er ikke nødvendigvis politiets skyld, og langt mindre resultat av at politiet gjør noe ulovlig. Det kan være innebygd i politiyrkets oppgaver - som å tvangsinnlegge en psykiatrisk pasient. Når en borger føler seg krenket og retter anklagen mot politiet, kan vi enkelt inndele det i tre kategorier: 1) politiet har gjort sitt beste. 2) politiet har gjort noen feil i måten å behandle personen på, men ikke noe ulovlig. 3) politiet har gjort noe ulovlig. Den siste typen skal innrapporteres for Spesialenheter for politisaker, men i Norge fører bare $1 \%$ av sakene til en tiltale og $5.5 \%$ til forelegg. De andre avvises for det meste som "straffbare forhold ikke bevist", "åpenbart grunnløs" og "intet straffbart forhold". ${ }^{51}$ Men noen av sakene får med seg en kritikk av enten ledelsen eller personen som var involvert. De færreste av klagene til Spesialenhetene og de som går til politiet selv, er egnet for strafferettslig behandling. En klagesang er til for å høres. Det er ikke en stil som det skal rettes i. Når ordensavdelingen på Stovner Politistasjon i Oslo får en skriftlig klage svarer de nesten uten unntak noe slikt som "at de beklager at de opplevde dette som en krenkelse..." ${ }^{52}$ Det kan virke litt sleipt, man sier beklager uten å ta på seg skyld - men det er av og til nok. Og ofte er det et godt utgangspunkt for en videre dialog og for "gjenopprettende rettferdighet". 
Undersøkelser i England viser at klagerne ønsker en samtale med politiet, mens politifolk er mindre positive. ${ }^{53}$ Når man selv har del i skylden for en konflikt, blir vår kompetanse i konflikthåndtering virkelig blir satt på prøve. Generelt virker systemene i Norden for hvordan politiet takler andres kritikk å være ganske usystematiske og svake. Og politiet mistenkes for "kameraderi" - om ikke å snakke sant om feil som kolleger begår. ${ }^{54}$

Det er to grunner til at dette må endres. Den første er taktisk. Den antiautoritære strømningen har vokst i folket gjennom flere generasjoner, med media som en spydspiss. Selvhøytidelige macho politifolk risikerer å bli ledd ut - særlig av den unge generasjon. Befolkningen vil reagere på maktmisbrukere som ikke er villig til å innrømme feil. Men dette er ikke bare snakk om taktikk. Taktikk kan bli taktløst. Den andre grunnen er prinsipiell, og bygger på en dyp forståelse av hva som støtter det overordnede målet for politiet: "rettsikkerhet, trygghet og alminnelig velferd." ${ }^{55}$ Etikkprofessoren Paul Leer Salvesen skriver: "Å vokse opp med en far som aldri innrømmer feil og aldri ber om tilgivelse for dårlig oppførsel, er sannsynligvis like skadelig som å vokse opp med en far som slår." ${ }^{56}$ Politiet er på en måte samfunnets far som setter grensene. Med kjønnsrolleutviklingen i politikorpset bør den også kunne ta en morsrolle? Politiet bør i hvert fall kunne bruke prinsippene for "gjenopprettende rettferdighet" når den "straffende rettferdighet" i Spesialenhetene anses som upassende. I Nord-Irland har politiet hatt en tragisk historie, og har måttet innstifte et eget ombud som hjelper folk med små og store klager på politiet. ${ }^{57}$

Framtidens politi som ønsker å stå for sannferdighet og rettsikkerhet, vil måtte begå feil nettopp fordi de står for høye idealer - og da er man nødt til å lære seg hvordan man arbeider med forsoning. I freds og tillitssirkelen er sannhet, rettferdighet, forsoning og sikkerhet verdier og holdninger som er gjensidig avhengig av hverandre, samtidig som de ofte kommer i innbyrdes spenning.

\section{Noter:}

Robert Reiner ("The Politics of the Police", Oxford University Press 2000) sier amerikanske krimserier gjengir et bilde med fire karakteristika: 1) Kriminaliteten er som regel alvorlig og voldelig, 2) De kriminelle er rasjonelle og målrettede, som regel høystatus middelaldrende hvite menn,

3) Politiet virker amatøraktig, mens de som framtrer profesjonelle som regel er enkeltpersoner eller privatdetektiver, 4) Forbrytelsene blir nesten alltid avslørt eller hindret, som regel gjennom eksepsjonelle individuelle prestasjoner. Alt dette er det motsatte av virkeligheten. Med et mulig unntak for pkt. 3, er det mitt inntrykk at dette gjelder for skandinaviske krimserier også.

2 James Q. Wilson ("Varities of Police Behaviour", Harvard University Press 1968) var en av de første som skrev om dette og anslo at bare $10-20 \%$ av politiets arbeid var kriminaltetsorientert. En revidert gjennomgang av dette av: Carl B. Klockars \& Jack Green ("What Police Do" i Carl B. Klockars et al (red): "Thinking About Police. Contemporary Readings", McGraw-Hill, New York 1991) anslår at det dreier seg om $30 \%$. 
3 Liv Finstad: "Politiblikket". Pax forlag, Oslo 2000. Denne undersøkelsen er ikke metodisk lagt opp slik at den er representativ for norsk politi. Den refererer til deler av Oslopolitiet og har ikke strenge utvalgsmetoder som sikrer tilfeldighet. På den andre side antas i følge vanlig kriminologisk innsikt antall pågripelser og innbringinger å være relativt større i storbyområder enn i resten av landet.

$4 \quad$ Lov 1995-08-04 nr. 53: Lov om politiet. § 2

$5 \quad$ Per Ole Johansen: "Menstad-konflikten 1931". Tiden, Oslo 1977 og Per Ole Johansen: "Samfunnets pansrede neve. Statspolitiets historie fra 1918 til 1941". Gyldendal, Oslo 1989

6 Lund-kommisjonen: www.stortinget.no/lund/ har saumfart norske politiets sikkerhetstjeneste nære historie, og gitt en sterk kritikk av ulovlig overvåking. Rune Glomseth ("Organisasjonskultur - En studie av organisasjonskulturen ved Beredskapstroppen, Oslo politidistrikt". Magisteruppsats Karlstad Universitet våren 2002) antyder en ganske normal norsk organisasjonskultur med vekt på bl.a. "rettssikkerhet og demokratiorientering" og "ydmykhetsorientering" ved siden av det mer forventede (?) som "prestasjonsorientering" og "handlingsorientering". Om Politiets Sikkerhetstjeneste i dag vet denne forfatteren intet, og om han visste noe, ville han holdt kjeft.

$7 \quad$ Ferdinand L. Næshagen ("Fra selvtekt til demokratisk politi" PHS Forskning 1999) nevner tre historiske særtrekk ved det norske politiet som har hindret denne militariseringen som har vært mer framtredende i f.eks. fransk og tysk politihistorie. Det første er den generelle fredelighet i landet, det andre er kontinuiteten/ konservatismen i lensmannstradisjonen og det tredje er politiets nære sammenvekst med det lokale samfunnet.

8 NOU 1981: 35 "Politiets rolle i samfunnet" og NOU 1987: 27 "Politiets rolle i samfunnet. Delutredning II:"

9 Jerome H. Skolnick ("Justice without Trial: Law Enforcement in a Democratic Society". John Wiley, New York 1966) introduserte dette temaet tidlig. I skandinavisk sammenheng har tre ferske doktorgradsarbeider konsentrert seg om politiets Ordne på stedet. Liv Finstad: op.cit., Lars Holmberg: "Politiets skøn i retssociologisk belysning. Ph.D. København Universitet 1999 og Rolf Granèr: "Patrullerande polisers yrkeskultur" Lund Dissertations in Social Work 18 2004. Et annet doktorgradsarbeid (Vidar Halvorsen: "Ethics, Force and Violence in Policing" Ph.D. Oslo Universitet 2002) gir en filosofisk-etisk belysning av politiets bruk av makt, vold, autoritet og skjønn.

10 En god introduksjonsbok er John Braithwaite: "Restorative Justice and Responsive Regulation" Oxford University Press 2002. Han gir også en kortfattet argumentasjon for og mot politiet som meglere. En kritisk gjennomgang er Declan Roche: "Accountability in Restorative Justice". Oxford University Press 2003. David Garland ("The Culture of Control" Oxford University Press 2001) mener at "Restorative Justice" ennå er svært perifer i forhold til den dominerende strafferettslige tenkning i dagens justissystem.

11 Prosjektet i Thames Valley Police kan finnes på: www.thamesvalley.police.uk/about/rj/index. $\underline{\text { htm }}$ og en evaluering som bl.a. finner signifikant nedgang i gjentagelseskriminalitet kan finnes på: www.jrf.org.uk/knowledge/findings/socialpolicy/542.asp En kritisk gjennomgang kan finnes hos Richard Young: "Just cops doing "shameful" business? Police-led restorative justice and lessons of research." i Gerry Johnstone (ed)"A Restorative Justice Reader". Willan Publishing 2003.

12 Forsøk med politiet som meglere blir evaluert av Politihøgskolens forskningsavdelingen ved Marit Egge.

13 For en talldiskusjon se R.J. Rummel: "Death by Government" Transaction Publishers 1994 og Ferdinand L. Næshagen: "Fra selvtekt til demokratisk politi” Politihøgskolens Forskning 1999

14 Nils Ringdal: "Mellom barken og veden. Politiet under okkupasjonen". Aschehoug, Oslo 1988 etterlater mange spørsmål: Hvorfor eskorterte politifolk tyske invasjonstyrker når de ankom Oslo? Hvorfor ble nesten halvparten av norske politifolk medlemmer i nazipartiet til tross for at det ikke forelå direkte tvang? Hvorfor gikk en så stor del av utrykningspolitiet og overvåk- 
ningspolitiet rett inn i det tyske statspolitiet? Hvorfor registrerte politiet kommunister og ga listene til tyskerne? Hvorfor brente de ikke etterretningsarkiver? Hvorfor deltok de så effektivt i arrestasjonen av 1100 lærere på to dager? Hvorfor deltok vanlig politi i sensurvirksomhet? Og det svarteste spørsmålet: Hvorfor gjorde politiet jøde-arrestasjonene så forbausende effektiv etter lang planlegging? Og nettopp fordi Ringdal også kan fortelle om politifolk som protesterte, ble arrestert og sendt i konsentrasjonsleire framstår disse andre handlingene i kontrast. Den samme kontrast gjelder en sammenligning med andre yrkesgrupper som prester og lærere.

Robert Rainer ("Politics of Policing". Oxford University Press 2000) gir en gjennomgang av hvordan politiet utvikles politisk i det engelske demokratiet. Norman S. J. Baxter ("Policing the Line". Ashgate 2001) behandler politiets forhold til sosiale opprørsbevegelser og streiker. Et norsk bidrag (Turid Heiberg et al: "Makt og langkølle. Søkelys på politiet". Tiden forlag Oslo 1989) er fra personer "som velger side, og ser politiets rolle i et kritisk perspektiv" (s. 11).

Helen Braithwaite et al. ("Conflict Management in Police-Citizen Interactions". Irwin/McGrawHill Sydney 1998) gir en oversikt over forskningsstatus med referanser. Ved gjennomlesning av skandinaviske studier; Liv Finstad op. cit, Lars Holmberg op.cit. og Rolf Granèr op.cit., kan man få det inntrykket at den svenske og danske doktorgraden synes å avsløre mer alvorlig misbruk av makt enn den norske. Det kan være reelle eller metodologiske forskjeller.

17 Noen forskere mener å ha registrert en vesentlig forskjell mellom kjønnene, hvor menn tenderer mot å bruke mer trusler, mer fysisk makt og røft språk. Andre forskere mener at det er liten forskjell. Se: Helen Braithwaite \& Neil Brewer:"Difference in the conflict resolution tactics of male and female patrol officers." i International Journal of Police Science \& Management. Volume 1 Number 3, 1998. I Norge finnes det lite forskning på kjønn og politiatferd $i$ tjenesten. Christin Thea Wathne ("Vi skjønte etter hvert at vi var kvinner". Hovedoppgave i sosiologi, Universitetet i Oslo 1992) støtter forskningen om systematiske kjønnsforskjeller i tjenesten. Liv Finstad op.cit.

19 Dette har vært ansett som aksiomer i politiforskningen, men blir nå motsagt ut fra en postmodernistisk forskningsretning. Se Phillip Chong Ho Shon: "Bringing the spoken words back in: Conversational zing police-citizen encounter research." i "Critical Criminology" 11: 2002. Helen Braithwaite op.cit.

21 "Vurdering av program og tiltak for å redusere problematferd og utvikle sosial kompetanse." Læringssenteret. Rapport 2000. Se også Thomas Nordahl: "Instrumentalisme og program for læring av sosial kompetanse". Prøveforelesning Dr. Politgrad, Universitetet i Oslo desember 2000.

Aslaug Mikkelsen et al: "Levekår og pensjon i norsk politi" Rogalandsforskning 2003. Politiinstruksen § 5-2 (FOR 1990-06-22 nr. 3963: Alminnelig tjenesteinstruks for politiet) nevner særskilt at "en politimann må ikke la seg provosere ved motstand eller fornærmelser". Selv med så tøffe arbeidsvilkår kan konflikter blant kolleger på arbeidsplassen være vel så stressende som konflikter $i$ arbeidet. Se Kristin Hellesø-Knutsen: "Belastninger og opplevd stress ved Operasjonssentralen, Oslo politidistrikt." Hovedfagsoppgave i psykologi, NTNU, Trondheim, våren 2003.

23 Uniform Crime Reports Section, FBI, U.S. Department of Justice: "A Study of Selected Felonious Killings of Law Enforcement Officers". September 1992.

24 Patrik Hennings \& Alexander Tilly: "Utbildning i vardagstaktik - svåre situationer". Upublisert. Polishögskolan 2003.

25 Live Bressendorf Lindseth ("Vis meg ditt kroppsspråk - og jeg skal si deg hva du oppnår". Kondor AS Forlag 2002) påstår at $90 \%$ av inntrykket skapes av stemmebruk og kroppsspråk, og bare $10 \%$ av ord. Det finnes flere påstander i flere bøker som angir forskjellige prosenter om kroppsspråk versus vanlig språk, men det er svært vanskelig å finne empiriske undersøkelser som underbygger det.

26 Virginia P. Richmond \& James C. McCroskey ("Nonverbal Behavior in Interpersonal Relations" Allyn and Bacon 2000) opererer med følgende felt for ikke-verbal kommunikasjon: 1) Physical 
Appearance 2) Gesture and Movement 3) Face and Eye Behaviour 4 )Vocal Behaviour 5) Space 6) Touch 7) Environment 8) Time.

${ }^{27}$ Kroppsspråk som vitenskapelig disiplin ble først etablert på 1960-tallet. Som i annen vitenskap blir sakene mer komplisert jo flere som forsker. Roger E. Axtell ("Kroppsspråkets skikk \& bruk verden rundt". EFI forlag, Oslo1991) viser til undersøkelser som mener at ansiktet er i stand til å produsere 250.000 uttrykk og at det finnes 5000 håndgestikuleringer som har verbal ekvivalens.

Særlig oppsikt vakte et BBC-program hvor en journalist hadde infiltrert politiet, og "The Stephen Lawrence Inquiry" (MacPherson Report). Denne rapporten som kom etter et rasistisk mord finnes på: www.archive.official-documents.co.uk/document/cm42/4262/4262.htm og tok opp temaet med "institusjonell rasisme" i det britiske politiet. Gurchard Singh ("Institutional racism" i Alan Marlow et al: "After McPherson. Policing after Stephen Lawrence inquiry". Russell House Publishing 2000) gir en nyansert analyse av mulig bruk av et slikt begrep. Den Europeiske Verdiundersøkelsen 1999.

30 Anthony Ansel-Henry og Susanne Branner Jespersen: "Konflikt på gadeplan - når etnisk minoritetsungdom og politi mødes". Center for Ungdomsforskning, Roskilde 2003.

31 Tor Tanke Holm \& Espen Barth Eide: "Peacebuilding and Police Reform" Frank Cass, London 2000.

32 Denne umetteligheten i velferdsstaten kan ha flere årsaker. David Garland ("The Culture of Control" Oxford University Press 2001) gir fire forklaringer: 1) De velferdsinstitusjonene som skal dekke folks behov, vil i sin indre logikk finne stadig nye behov, 2) Velferdsøkning fører til økte forventninger, 3) Byråkratiet blir formynder og overser folks evne til selv å løse konflikter, 4) Den lange velferdsperioden skjuler de problemer som den har løst, folk glemmer depresjonen og ser problemene i en stat som ikke leverer. I tillegg kan jeg nevne faktorer som den økende ensligheten i samfunnet og folks usikkerhet overfor den økende profesjonaliseringen, som fører til at folk lettere vil henvende seg til politiets telefonnummer: 112. NOU 1981: 35 "Politiets rolle i samfunnet" s. 73.

34 Statistikken om antall politi i forhold til folketall er hentet fra en brosjyre i den finske politiskolen og gjelder året 1994. Den tilsvarende statistikken som finnes i FNs kriminalstatistikk bruker svært forskjellige kriterier for hva som er en politistyrke. Dette vil uansett være et problem ved en slik statistikk, og den skal derfor tas med en teskje salt. Statistikken om tillit til politiet er hentet fra World Values studies 1999-2000.

35 Nils Christies artikkel: "Conflict as property", som ble skrevet i 1977 (og finnes i Gerry Johnstone:”A Restorative Justice Reader" Willan Publishing 2003) var en svært viktig inspirasjon for den moderne meglerbevegelsen. Jeg våger den påstand at den er den mest siterte artikkel fra samfunnsforskningen i Norge

36 På Nordisk Forum for Meglings hjemmeside: www.n-f-m.org vil man finne oversikt over mer enn 80 organisasjoner i de nordiske land som engasjerer seg for megling og frivillig, fredelig konflikthåndtering.

37 Dagbladet Magasinet 29. april 2004 gjengir en undersøkelse som viser at 9 av 10 har liten eller ingen tiltro til at politiet vil oppklare en sak om en stjålet lommebok, 7 av 10 har samme mistro til at tyveri i huset vil bli oppklart og 5 av 10 har mistro til at politiet vil oppklare en voldssak.

38 Dette behandles bl.a. av Lars Holmberg op.cit. og Tom R. Tyler \& Yuen Huo: "Trust in the Law". The Russell Sage Foundation 2002. En undersøkelse som spiller opp til en slik PR-strategi for politiet er: Russell Bradley: "Public Expectations and Perceptions of Policing". Police Research Series Paper 96, United Kingdom 1998.

39 John Paul Lederach: "The Journey towards Reconciliation". Herald Press 1999 og: "Building Peace. Sustainable Reconciliation in Divided Societies". United States Institute of Peace Press 1997.

40 "Politikultur" er et gjennomgangstema i politiforskningen, hvor man beskriver diverse karakteristika ved politiets væremåte. Noen bruker andre begreper som "arbeidspersonlighet" (Jerome 
H. Skolnick op.cit.) og "politiblikket" (Liv Finstad op.cit.). Problemet med bruk av begrepet "politikultur" er at det finnes forskjellige subkulturer innen politiet, og at den som kulturer flest endrer seg over tid. Jeg foretrekker derfor å bruke ordet i flertall.

${ }^{41}$ NOU 1981: 35 "Politiets rolle i samfunnet".

42 Denne debatten er bl.a. reist av Rune Slagstad i boka: "De nasjonale strateger". Pax forlag, Oslo 1998 .

${ }_{43}$ Stortingsmelding nr. 22, 2000-2001: "Politireform 2000".

44 Riksadvokatens rundskriv nr. 1/2004 Ra 04-46 820.6: "Mål og prinsipper for straffesaksbehandling i politiet 2004". Den norske Riksadvokaten nevner også "høy kvalitet" som mål, men dette kvantifiseres ikke. I tillegg kvantifiserer han et par områder innen "adekvat reaksjon", bl.a. 30 $\%$ økning av saker til konfliktrådet, som synes å ha fått en rask oppfølging i politiet. Dette viser tallenes betydning for konkret handling.

45 F.eks. viser tall fra Danmark at det er ingen sammenheng mellom oppklaringsprosent og nivå på kriminalitet, og videre at enkelte steder går antall forbrytelser ned, mens folks frykt for forbrytelser går opp. Lars Holmberg: "Det personlige politi”. Rigspolitichefens Trykkeri, København 2001.

46 Se fotnote 42.

47 De fleste samfunnsforskere vil tilskrive veksten i kriminalstatistikken de siste 40 årene til samfunnsutviklingen generelt og ikke til endringer i det strafferettslige system. Johs Andenæs, senioren i norsk strafferett, gir en oppsummering av dette i det siste kapittelet i: "Straffen som problem", Exil Forlag 1994.

48 Politidirektoratet driver forsøk med "Politimesterens styringsverktøy" i noen politidistrikt. Intensjonen er å lage indikatorer for bl.a. publikums og medarbeideres tilfredshet og omfang/ innhold i arbeidet. Personlig kommunikasjon: Knut Engan.

49 Anne Marie Stökken: "Politiet i det norske samfunn". Universitetsforlaget, Oslo 1974 s. 199 ff.

50 Rogaland Politidistrikt Publikumsundersøkelse 2002. Markedsføringshuset AS.

51 Gunnar Thomassen: "SEFO. Det særskilte etterforskningsorgan. En empirisk belysning" PHS Forskning 1999. Tallene er fra 1995-1996.

52 Personlig kommunikasjon: Tom Østreng.

53 England, som i motsetning til Norge har utviklet et system for uformell klagebehandling, kan rapportere at dette er bedre enn den formelle/ strafferettslige tilnærming, men de har fortsatt store problemer. To rapporter vurderer dette fra henholdsvis klagernes og politiets side: Hamish Warburton et al: "Opposite Sides of the Same Coin: Police Perspectives on Informally Resolved Complaints". The Police Foundation, London 2003, og Ian Waters \& Katie Brown: "Police complaints and the complaints experience" i British Journal of Criminology 40, 2000. I England finnes også en omfattende teoretisk diskusjon om temaet, se f.eks.: Andrew J. Goldsmith (ed): "Complaints Against the Police. The Trend to External Review." Clarendon Press Oxford 1991.

54 Et par saker fra et par tiår tilbake i Norge; "Politivoldsaken" i Bergen og "Maridalsaken" satte søkelys ikke bare på politiets maktbruk, men også om politiet snakker sant eller lyver. Se: Anders Bratholm: "Politi, påtalemyndighet, presse og rettssikkerhet: politivoldsaken i Bergen - foran og bak kulissene." Aschehoug, Oslo 1999 og for en generell drøfting av disse synspunktene: Liv Finstad op.cit.

55 Lov 1995-08-04 nr. 53: Lov om politiet. § 1.

56 Paul Leer Salvesen: "Min skyld". Verbum 2002, side 23.

57 Se: www.policeombudsman.org

Adress:

Nordisk Forum for Megling og Konflikthåndtering

Pareliusveien 7a

NO-1177 Oslo 